\title{
ОГЛЯДИ, РЕЦЕНЗІї
}

DOI: $10.26565 / 2227-6505-2019-28-09$

Чорний Д.М. Рецензія на Яцина Олег. Старовинний Харків: історія, житло, архітектура [Альбом] / Вступна ст. В. Завершинський / наук. ред. серії проф. О. Коляструк. Харків: «Раритети України», 2018. 184 с.

Харківський національний університет імені В. Н. Каразіна d.chornyi@karazin.ua,https://orcid.org/0000-0001-9149-9203

Нова книга шанованого в Харкові історика, громадського діяча Олега Анатолійовича Яцини належить до науково-популярних видань. Автор продовжує знайомити мешканців та гостей міста із архітектурою обласного центру, розпочате книгою «Архітектурна симфонія Харкова», виданою 2008 р. Рецензоване видання добре вписується у низку публікацій останніх часів, які допомагають розкрити архітектурне обличчя столиці Слобідської України від давнини до сучасності. Підкреслимо, що увага до «образів міста» знаходиться в тренде сучасного наукового дискурсу, а тому появу даної книжки треба вітати.

Видання складається із звернення «До читача», написаного Валерієм Завершинським, авторського вступу до читача «Місто та його історія», трьох розділів «Вільне житлове будівництво», «Становлення регулярного житлового будівництва», «Формування підгрунтя сучасного житлобудування» та післяслова «Сучасний образ Харкова в його вулицях». В першому розділі висвітлено «Заснування Харкова: ланшафт, територія, населення» (с. 17-29), «Формування вулиць. Двори» (с. 29-30), «Житло харків'ян та його еволюція у XVII - до кін. XVIII ст.» (с. 31-43), «Організація житлового будівництва» (с. 43-49). В другому розділі автор зосередив увагу на таких аспектах, як «Фактори зростання м. Харкова в кін. XVIII cер. XIX ст.» (с. 51-62), «Початок планового розвитку міста» (с. 63-66), «Впровадження кам'яного житлобудування» (с. 67-101), «Харківські цвинтарі» (с. 101-105). В третьому розділі висвітлено такі проблеми, як «Фактори зростання Харкова у кін. XIX - на поч. XX ст. та його топографія» (с. 107-124), «Децентралізація у будівництві: причини та наслідки» (с. 125-134), «Диференціяція житла та розмаїття архітектурних стилів» (с. 136-166). Додатки на c. 174-181 подають фотокопію з документа кінця XIX ст. про перейменуванням вулиць. Зважаючи на широкий суспільний резонанс, який викликала робота топонімічної комісії в Харкові у 2015 р., здійснені зміни комуністичних назв вулиць міста, боротьбу, що не припиняється сьогодні навколо вшанування тих чи інших діячів, подібний матеріал $\epsilon$ доречним і повчальним.

Беззаперечним позитивом видання є чітко витриманий курс на альбомний характер. У ньому вміщено, проаналізовано, прокоментовано 144 пронумерованих ілюстрацій, які включають високоясні сучасні фотографії будинків, що належать до різних епох, архітектурних стилів і слугували житлом для представників різних соціальних верств (с. 3233, 39, 72, 134-135 та ін.), близько 20 планів та карт міста Харкова 1742-1932 pp. (с. 23, 55, $59,60,64,65,111,114-115,116,117,118,122,129$ ), проекти фасадів та внутрішніх кімнат будинків, дворових ділянок ( с. $35,38,40,42,47,68,79,90,123)$, старовинні фото (с.20, 21 , $36,58,102,103)$. Вміщені фотографії подають картину житлового будівництва в різних районах міста, допомагають скласти уявлення про різні типи споруд від хати мазанки, обшитих дошкою будиночків на околицях до багатоквартирних прибуткових будинків початку XX ст. Автором докладно представлено не лише загальний архітектурний вигляд споруд, але і привернуто увагу до елементів фасаду, декору. Дуже рідкісною з точки зору витворення образів старовинного Харкова $є$ увага О.А. Яцини до внутрішніх двориків (с. $100,126)$, будинків, що руйнуються або зникли з харківських вулиць (с.69, 89, 104),

СЧорний Д. М., 2019 
дерев'яних галерей та сходів (їх наявність суспільна свідомість чомусь пов'язує лише із Одесою), ажурних балконів (с. 88, 91, 92) тощо.

Попри в цілому позитивну оцінку видання, маємо висловити деякі міркування, на які мене, як читача, наштовхує будь-яка цінна книжка. Адже «споживач» літературного продукту завжди бажає більшого. По-перше, залишилося не зрозумілим, чому в альбомі є не пронумеровані і не прокоментовані фото: с. 12, 14, 15, 48, 50, 106, 172. Серед поданих на цих сторінках зображень є знакові будинки, як приміром на с. 106 - монументальна споруда на Полтавському шляху. Очевидно, людині, яка вперше буде знайомитися із Харковом, тримаючи в руках даний альбом, потрібно було б пояснити походження таких будинків.

По-друге, наведені зображення карт та планів міста мають беззаперечну цінність. Всі вони є бібліографічною рідкістю і залишається висловити жаль, що частина з їх фото занадто дрібні. Можливо, автору варто подумати над виданням альбому карт та планів міста в великому форматі. Таким чином вони стануть доступними широкому загалу не лише охочих познайомитися із минулим міста, а й фахівцям-урбаністам.

По-третє, підрозділ 2.4, присвячений Харківським цвинтарям, складається лише із тексту і не містить жодного візуального зображення. У світовій урбаністиці історія міських кладовищ як місця останнього прихистку померлого, набуває все більшого значення. Тож, очевидно, Харків заслуговує на увагу до цієї теми, що й зафіксував своєю книгою О.А. Яцина.

Підбиваючи підсумок, маємо зазначити, що література з історії Харкова збагатилася ще одним цінним виданням, яке буде корисним новим мешканцям міста, молоді. Воно сприятиме вихованню любові та поваги до місцевих архітектурних цінностей, збереженню історичної пам’яті. 